\title{
Body size and age structure of Lacerta agilis LINNAEUS, 1758 (Reptilia: Lacertidae) from two different populations in Turkey
}

\author{
Kamil CANDAN *1,2 \\ ORCID: 0000-0002-6934-3971
}

\author{
${ }^{1}$ Dokuz Eylül University, Faculty of Science, Department of Biology, 35390, Buca, İzmir, Turkey. \\ ${ }^{2}$ Dokuz Eylül University, Fauna and Flora Research and Application Center, 35390, Buca, İzmir, Turkey
}

\begin{abstract}
Age structure and longevity in 47 museum specimens (31 females and 16 males) of Lacerta agilis from two different populations in Turkey were skeletochronologically studied. The mean SVL of males was not significantly different from those of females, although intersexual differences in body size are female-biased. The age structure ranged from 3 to 6 years in male individuals, and 3 to 8 years in females. Age at sexual maturity was 2 years for males, while females reached sexual maturity after the third year of life. The age did not significantly differ between the sexes. Additionally, age structure and SVL did not significantly differ between the two populations. A significant positive correlation between SVL and age structure was present for the Kars population, although there was a weak correlation for the Ardahan population. Considering sex, there was a significant difference in terms of SVL for the Ardahan population, while age structure significantly differed for the Kars population.
\end{abstract}

Keywords: Skeletochronology, Lacertidae, Lacerta agilis, Turkey

\section{Türkiye'deki iki farklı populasyondan Lacerta agilis'in LINNAEUS, 1758 (Reptilia: Lacertidae) vücut büyüklüğü ve yaş yapısı}

\section{Özet}

Türkiye'deki iki farklı popülasyondan Lacerta agilis'in 47 müze örneğinde (31 dişi ve 16 erkek) yaş yapısı ve yaşam süresi iskelet kronolojisi kullanılarak incelenmiştir. Cinsiyete bağımlı vücut büyüklüğü dişi eğilimli olmasına rağmen, erkeklerin ortalama SVL'si dişilerden önemli ölçüde farklı değildir. Yaş dağılımı erkek bireylerde 3 ile 6 yıl arasında, dişilerde ise 3 ile 8 yıl arasında değişmektedir. Erkekler iki, dişiler ise yaşamın üçüncü yılından sonra cinsel olgunluğa ulaşır. Yaş, cinsiyetler arasında önemli ölçüde farklılık göstermez. Bununla birlikte, yaş yapısı ve SVL iki popülasyon arasında önemli ölçüde farklı değildir. SVL ile yaş arasında Ardahan popülasyonu için zayıf bir korelasyon olsa da Kars popülasyonu için anlamlı ölçüde bir pozitif korelasyon vardır. Cinsiyetler göz önüne alındığında, Ardahan popülasyonunda SVL için, Kars popülasyonda ise yaş dağılımı için anlamlı bir fark söz konusudur.

Anahtar kelimeler: İskelet kronolojisi, Lacertidae, Lacerta agilis, Türkiye

\section{Introduction}

The Sand Lizard, Lacerta agilis Linnaeus, 1768, is widely distributed in the Palearctic and extends from north (Sweden, Finland, and southern Great Britain to northern Greece) to south (Caucasus) and west (Pyrenees) to east (northwest China) [1]. In Turkey, it is known from northeastern Turkey including Erzurum, Ardahan, Kars, Artvin, and Trabzon provinces [2]. Lacerta agilis is a closely related species belonging to the subgenus Lacerta s. str. (= Lacerta I group sensu) and is a medium-sized, diurnal, insectivorous lizard [3]. This species is listed as LC (Least Concern) in the

\footnotetext{
* Corresponding author / Haberleşmeden sorumlu yazar: Tel.: +902323018000; Fax.: + 9023245341 88; E-mail: kamil.candan@ deu.edu.tr

(C) Copyright 2021 by Biological Diversity and Conservation $\quad$ Geliș tarihi: 06.09.2021; Yayın tarihi: 15.12.2021 
IUCN Red List of Threatened Species because of its wide distribution, tolerance of a degree of habitat modification, and presumed large population. It is unlikely that its population will decline fast enough to qualify for listing in a more threatened category [4].

The age structure of a population, which is by nature related to its life history $[5,6]$, is defined by demographic parameters [7], and reveals important features of individuals such as age and size at maturity, frequency of reproduction, clutch or litter size and hatchlings, and survivorship [8, 9]. Nevertheless, variation in some traits, such as offspring size or egg and number, is frequently associated with species body size, and egg or offspring number is generally associated with female size within species [10]. The skeletochronology method, which is based on the presence of growth layers in bone tissue, is very useful in calculating the age of lizards [11]. This method shows that when bone growth is interrupted because of seasonal marks or slowed because of natural biological rhythms, rings representing arrested growth (LAGs) can occur in animals like reptiles [12], and it was used successfully in many studies of the family Lacertidae [5, 6, 9, 13]. However, data about age structure, senescence, and reproductive life span are still not available for the vast majority of reptile species [10]. Therefore, the studies related to age and growth estimation of this species with wide distribution using skeletochronology are quite limited [3, 14, 15, 16, 17, 18]. This study aimed to obtain data about the age structure, life history and some growth parameters of L. agilis in two different populations from Turkey.

\section{Materials and methods}

\subsection{Study sites and specimens}

A total of 47 (31 females and 16 males) lizard specimens were used from two different populations of L. agilis (Çayağazı Village, Ardahan Province: 41.193240N-42.856007E, 1766 m a.s.l. and Mescitli Village, Kars Province: 40.252579N-42.647452E, $2037 \mathrm{~m}$ a.s.1.). All specimens were obtained from the museum collection in the Zoology Lab of the Department of Biology in the Science Faculty, Dokuz Eylül University (Collection numbers: ZDEU-113.2011, ZDEU-319.2013). To obtain bone samples for skeletochronology analysis, the toe of each individual was taken using a single digit from the back-right foot. Then, the toes were placed in an Eppendorf tube containing $96 \%$ ethanol. Afterward, they were kept at $+4{ }^{\circ} \mathrm{C}$ for skeletochronology. The sex of the lizards was determined by examining of the secondary sexual characters (overall coloration, larger head, and more developed femoral pores in males and developing eggs in females). The snout-vent lengths (SVL) of specimens were measured using a digital caliper compass with an accuracy of $0.01 \mathrm{~mm}$.

\subsection{Skeletochronology}

The standard procedure was used for skeletochronology $[5,13,19,20]$. The phalanges, those preserved in $96 \%$ ethanol solution, were washed in tap water for $24 \mathrm{~h}$ to remove alcohol and then decalcified in $5 \%$ nitric acid solution for $2 \mathrm{~h}$. The phalanges were washed again in tap water for approximately $12 \mathrm{~h}$ after decalcification. The cross-sections (16 $\mu \mathrm{m}$ of thickness) were taken from the diaphyseal region of the phalanx by using a rotary microtome and then stained with Ehrlich's hematoxylin. All the sections were examined under a stereomicroscope targeting selection of good sections. All photos were examined, and the analysis of LAGs (lines of arrested growth) was performed by different researchers according to the previous technique that is standard. Double lines were disregarded for age determination. The distance between two adjoining LAGs is a good indicator of individual growth in a given specimen. Any obvious decrease in space between two subsequent LAGs was taken as an indicator of the age of sexual maturity [21]. Age at sexual maturity was determined by considering the distance between the two adjoining LAGs. The proportion of endosteal resorption (the bone remodeling process that might have reabsorbed part of the entire LAGs = ER) was assessed by comparing the diameters of eroded marrow cavities with the diameters of non-eroded marrow cavities [22].

\subsection{Climatic data}

Climatic data for both populations were obtained from the Turkish State Meteorological Service [23]. Monthly average temperature and precipitation data were collected for the measurement periods between 1927 and 2018.

\subsection{Statistical analyses}

The normality of the SVL and age distribution for each population was tested with the Kolmogorov-Smirnov test $(P>0.05)$. After variables were detected to have normal distribution, parametric tests were applied to test significant differences. Non-parametric tests were used when variables were not normally distributed. The difference between SVL and age between sexes were analyzed with both the Student t-test and Mann-Whitney U-test. Spearman's correlation coefficient was used to infer the relationships between age and SVL. Regression analysis was performed by using the quadratic model, which had the highest $\mathrm{R}^{2}$ value. All statistical tests were performed with IBM SPSS 23.0 for Windows. 
A size dependent dimorphism index (SDI) aiming to exhibit the degree of sexual size dimorphism (SSD) was used by following [24]:

$\mathrm{SDI}=[$ (mean length of the larger sex / mean length of the smaller sex $) \pm 1]$

+1 if males are larger or -1 if females are larger. It is defined as positive whenever females are larger than males and negative in the converse case.

\section{Results}

LAGs were counted on phalangeal cross-sections in Figure 1. Although endosteal resorption was observed in 30 individuals $(63,8 \%)$, it was not difficult to determine the age of specimens. Double lines were observed in 13 $(27,6 \%)$ specimens. The age at sexual maturity was 2 and 3 years for males and females of L. agilis, respectively.

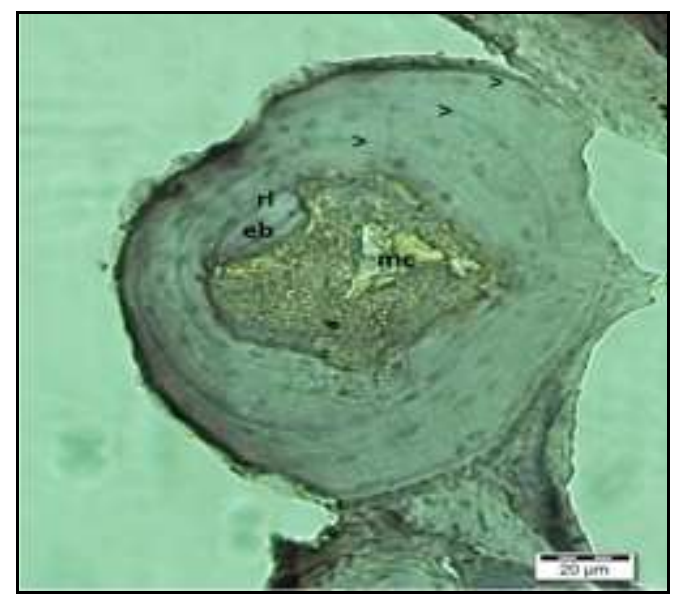

Figure 1. A cross-section at the diaphysis of a phalanx of Lacerta agilis with 3 LAGs. eb, endosteal bone; mc, marrow cavity; rl, resorption line. (SVL of the specimen: $61.3 \mathrm{~mm}$ ).

\subsection{The Ardahan population}

Descriptive statistics for age and SVL are given in Table 1. Mean SVL and age were $76.26 \pm 1.62 \mathrm{~mm}$ and $5 \pm$ 0.26 years in males and $65.62 \pm 3.42 \mathrm{~mm}$ and $4.33 \pm 0.31$ years in female specimens. Intersexual differences in body size were female-biased (SDI: 0.74). There were significant differences in terms of SVL between sexes (Independent $\mathrm{t}-$ test: $P=0.04$ ), whereas age did not differ between female and male specimens (Mann-Whitney $\mathrm{U}$-test: $\mathrm{U}=36, P=$ 0.10 ). In both sexes, there was no correlation between SVL and age structure (Spearman's correlation, males, $r=-231$, $P=0.058$; females, $\mathrm{r}=427, P=0.11)$. The exponential regression is similar to Spearman's correlation between SVL and age $(\mathrm{y}=45.23+5.28 * \mathrm{x})$ (Figure 2$)$. The maximum longevity was seven years for the Ardahan population.

\subsection{The Kars population}

Descriptive statistics for age and SVL are given in Table 1. Mean SVL and age were $71.97 \pm 2.33 \mathrm{~mm}$ and $4.13 \pm 0.22$ years in males and $76.14 \pm 2.82 \mathrm{~mm}$ and $5.13 \pm 0.32$ years in female specimens. Intersexual differences in body size were female-biased (SDI: 0.49). There were no significant differences in terms of SVL between sexes (MannWhitney $\mathrm{U}$ test: $\mathrm{U}=42, P=0.17)$. Also, age structure did not indicate a significant difference between female and male specimens (Independent t-test: $P=0.55$ ). In both sexes, a significant positive correlation was recorded between SVL and age structure (Spearman's correlation, males, $\mathrm{r}=784, P=0.02$; females, $\mathrm{r}=791, P=0.000$ ). The exponential regression fit Spearman's correlation between SVL and age $\left(y=45.28+6.15^{*} \mathrm{x}\right)$ (Figure 3). The maximum longevity was eight years for the Kars population.

Table 1. Descriptive statistics of populations of L. agilis.

\begin{tabular}{|c|c|c|c|c|c|c|c|c|c|}
\hline Parameters & \multicolumn{3}{|c|}{ the Ardahan population } & \multicolumn{3}{c|}{ the Kars population } & \multicolumn{3}{c|}{ Total } \\
\hline & $\mathrm{N}$ & Mean \pm SE & Range & $\mathrm{N}$ & Mean \pm SE & Range & $\mathrm{N}$ & Mean \pm SE & Range \\
\hline Females & 15 & & & 16 & & & 31 & & \\
\hline SVL (mm) & & $65.62 \pm 3.42$ & $49.40-92.70$ & & $76.14 \pm 2.82$ & $47.10-94.50$ & & $71.05 \pm 2.37$ & $47.10-94.50$ \\
\hline Age (years) & & $4.33 \pm 0.31$ & $3-7$ & & $5.13 \pm 0.32$ & $3-8$ & & $4.74 \pm 0.23$ & $3-8$ \\
\hline Males & 8 & & & 8 & & & 16 & & \\
\hline SVL (mm) & & $76.26 \pm 1.62$ & $70.70-83.40$ & & $71.97 \pm 2.33$ & $62-81.60$ & & $74.11 \pm 1.48$ & $62.00-83.40$ \\
\hline Age (years) & & $5 \pm 0.26$ & $4-6$ & & $4.13 \pm 0.22$ & $3-5$ & & $4.56 \pm 0.81$ & $3-6$ \\
\hline
\end{tabular}



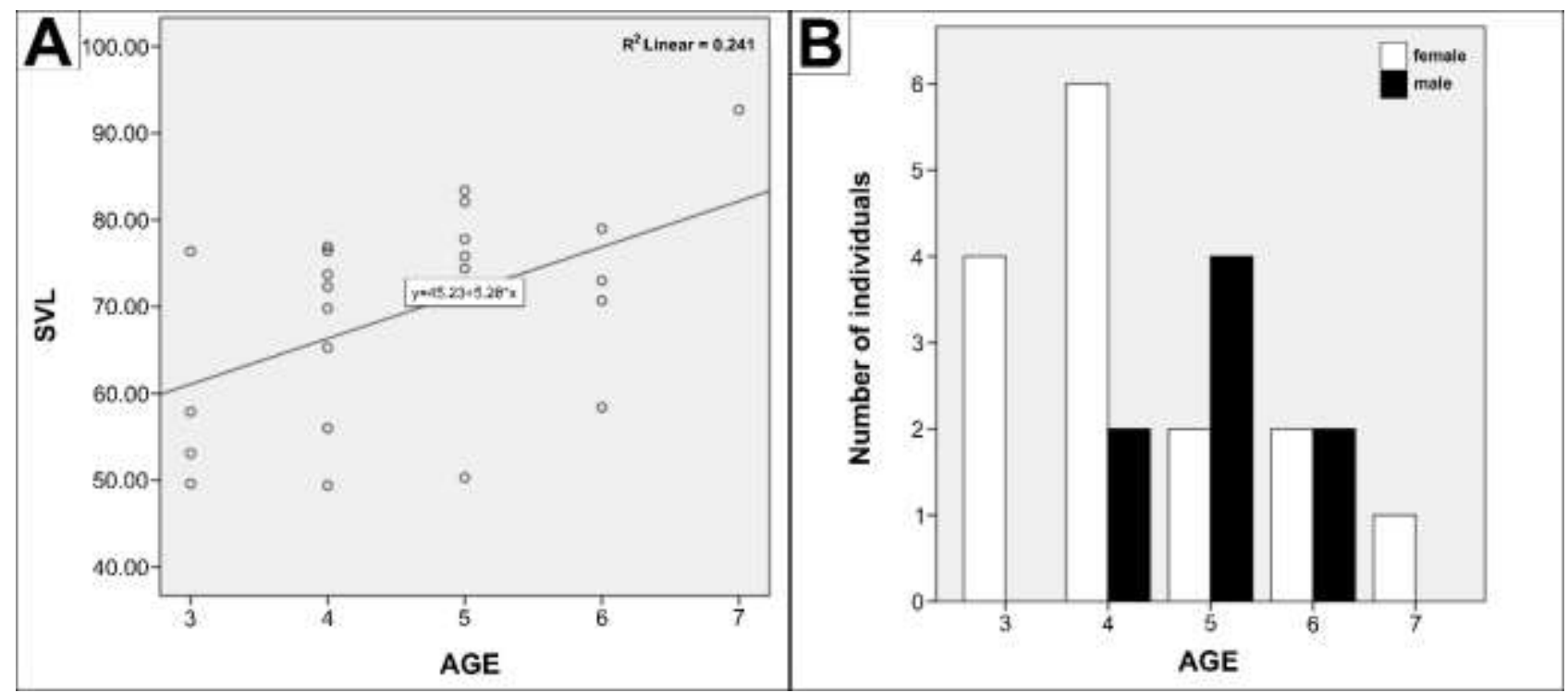

Figure 2. (A) Regression of SVL on age in L. agilis from the Ardahan population. (B) Age distribution of males and females in L. agilis from the Ardahan population.
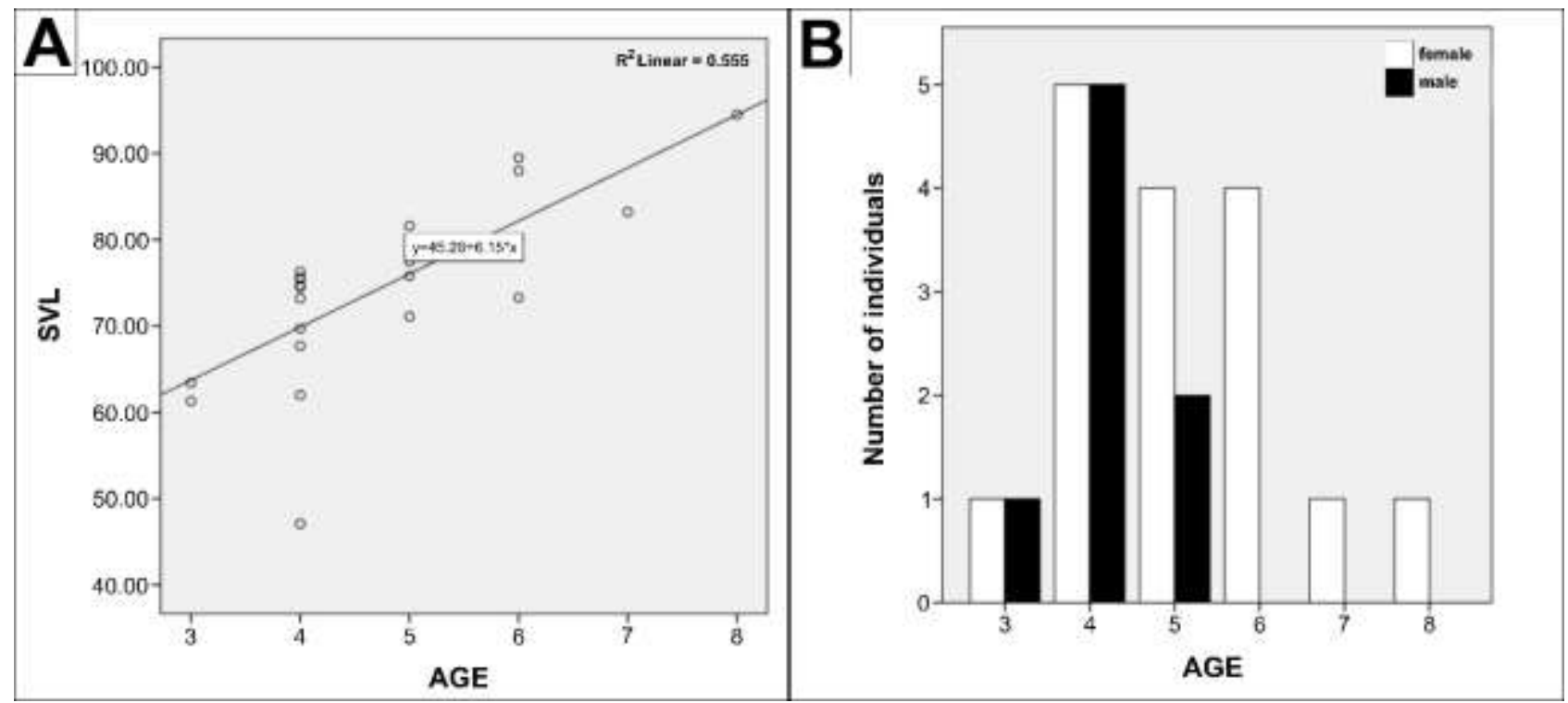

Figure 3. (A) Regression of SVL on age in L. agilis from the Kars population. (B) Age distribution of males and females in L. agilis from the Kars population.

\subsection{Climatic data}

Both temperature and precipitation data indicated normal distribution according to the Shapiro-Wilk test $(0.05$ $<P)$. In the independent samples test, Levene's test indicated that the variances of the groups were homogeneous with 95\% confidence ( $\mathrm{F}=0, P=0.997 ; \mathrm{F}=0.934, P=0.344$ for precipitation). Consequently, there was no difference for both populations in terms of precipitation $(\mathrm{t}=0.462, \mathrm{df}=22, P=0.648)$. Similarly, the temperature did not indicate extreme differences between the populations $(\mathrm{t}=-0.244$, $\mathrm{df}=22, P=0.809)$.

\section{Discussion and conclusion}

The skeletochronological method was applied to specimens of Lacerta agilis from different populations and the first data about age structure and body size were obtained in Turkey. The longevity of L. agilis was estimated to be 8 years in females and 6 years in males. The maximum longevity of L. agilis is comparable to that of other related lizards, such as Ophisops elegans [25] and Psammodrous algirus [26], but lower than Acanthodactylus boskianus [13] and Eremias suphani [6]. The maximum longevity of L. agilis from Dagestan (Russian) was 6-7 years for males and 5-6 years for females [3], whereas age ranged from 2-4 years in males and 3 years in females of L. agilis from Italy [16]. 
[15] reported that the maximum longevity of the same species from Sweden was 12 years for females and 11 years for males. On the other hand, [27] reported that the maximum longevity in a high population of Darevskia clarkorum was 12 years, whereas longevity was 10 years in low populations. It seems that age structure and longevity in lizards are variable among populations of the same species. Furthermore, this variation in longevity is probably a result of physiological features, the effect of predators and parasites [28].

In the results, the mean SVL had a significant difference between sexes in the Ardahan population, but there was no difference in terms of SVL between male and female individuals from the Kars population; in addition to this, SSD of both populations was female-biased. However, [29] pointed out that male individuals were larger than female individuals in the majority of lizards; moreover, they stated that male-biased SSD was the rule in several families like Lacertidae, but this rule is not always valid because this status can change in many lizard species (Podarcis tauricus [30]; Apathya cappadoccica [19]; Carlia rostralis [31]; Phoenicolacerta laevis [9] for male-biased SSD; Darevskia derjugini [32]; Carlia storri [31] for female-biased). [29] also stated that SSD variation between male and female individuals of a single species was associated with population differences based on environmental conditions like altitude, latitude, and climate. In addition, in another study, L. a. agilis (female-biased) and L. a. boemica (male-biased) showed a clear contrast concerning SSD, and it was stated to occur in ecogeographical clines within subspecies of $L$. agilis with more male-biased SSD in warmer climates [33]. According to observations, there was no difference for $L$. agilis in terms of climatic conditions between Ardahan and Kars regions; that is, annual average temperature and precipitation in Ardahan were $3.9 \mathrm{C}^{\circ}$ and $555 \mathrm{~mm}$, whereas annual average temperature and precipitation in Kars were $4.9 \mathrm{C}^{\circ}$ and $500 \mathrm{~mm}$, respectively, according to measurement period between 1927 and 2018 [23]. Furthermore, this status was statistically supported. The female-biased SSD in populations of L. agilis for both regions may be due to reproductive success because the body size of female individuals is strongly correlated with fecundity in many animal species, whereas the body size of male individuals was correlated with mating success [34]. Additionally, [35] pointed out that reproductive characteristics like fecundity selection can explain the relationship to sexual size dimorphism (SSD) in L. agilis. Also, it was shown that species which are female-biased SSD are also oviparous and viviparous [34]. This applies to L. agilis, which is an oviparous lizard.

In conclusion, life-history traits such as age structure, body size, longevity, and sexual maturity were studied for L. agilis from Turkey. In this study, all populations of L. agilis had female-biased SSD. The results supported that the effect of sexual selection was probably weaker than selection on fecundity in this species because the climatic conditions of both populations did not have an important effect on SSD.

\section{References}

[1] Andres, C., Franke, F., Bleıdorn C., Bernhard, D., \& Schlegel, M. (2014). Phylogenetic analysis of the Lacerta agilis subspecies complex. Systematics and Biodiversity, 12, 43-54.

[2] Baran, İ., \& Atatür, M. K. (1998). Turkish Herpetofauna (Amphibians and Reptiles). Turkish Republic of Environmental Ministry, Ankara.

[3] Roitberg, E. S., \& Smirina, E. M. (2006). Age, body size and growth of Lacerta agilis boemica and L. agilis strigata: a comparative study of two closely related lizard species based on skeletochronology. Herpetological Journal, 16, 133-148.

[4] Agasyan, A., Avc1, A., Tuniyev, B., Lymberakis, P., Andren, C., Cogalniceanu, D., Wilkinson, J., Ananjeva, N., Üzüm, N., Orlov, N., Podloucky, R., Tuniyev, S., Kaya, U., Crnobrnja-Isailovic, J., Vogrin, M., Corti, C., PerezMellado, V., Sa-Sousa, P., Cheylan, M., Pleguezuelos, J., Kyek, M., Westerström, A., Nettmann, H. K., Borczyk, B., Sterijovski, B., \& Schmidt, B. (2010). Lacerta agilis. The IUCN Red List of Threatened Species 2010: e.T157288A5071439.http://dx.doi.org/10.2305/IUCN.UK.2010-4.RLTS.T157288A5071439.en.

[5] Gül, S., Özdemir, N., Kumlutaş, Y., \& Ilgaz, Ç. (2014). Age structure and body size in three populations of Darevskia rudis (Bedriaga, 1886) from different altitudes. Herpetozoa, 26, 151-158.

[6] Üzüm, N., Avc1, A., Kumlutaş, Y., Beşer, N., \& Ilgaz, Ç. (2015). The first record of age structure and body size of the Suphan Racerunner, Eremias suphani Başoğlu \& Hellmich, 1968. Turkish Journal of Zoology, 39, 513518.

[7] Stearns, S. C., \& Koella, J. (1986). The evolution of phenotypic plasticity in life-history traits: predictions for norms of reaction for age and size-at-maturity. Evolution, 40, 893-913.

[8] Bauwens, D. (1999). Life history variation in lacertid lizards. Natura Croatica, 8, 239-252.

[9] Üzüm, N., Ilgaz, Ç., Avcı, A., Candan, K., Güler, H., \& Kumlutaş, Y. (2018). Comparison of the body size and age structure of Lebanon lizard, Phoenicolacerta laevis (Gray, 1838) at different altitudes in Turkey. Vertebrate Zoology, 68, 83-90.

[10] Vitt, L. J. (2016). Reptile diversity and life history. p. 3-15. In: Jr. C. K. Dodd (ed.), Reptile Ecology and Conservation. A Handbook of Techniques. Oxford University Press, Penrith, Cumbria.

[11] Castanet, J., \& Smirina, E. M. (1990). Introduction to the skeletochronological method in amphibians and reptiles. Annales Des Sciences Naturelles, 11, 191-196. 
[12] Green, C.C. (2018). Osteohistology and Skeletochronology of An Ontogenetic Series of Clidastes (Squamata: Mosasauridae): Growth and Metabolism in Basal Mosasaurids. Unpublished master's thesis. Fort Hays State University, Kansas.

[13] Üzüm, N., Ilgaz, Ç., Kumlutaş, Y., Gümüş, Ç., \& Avc1, A. (2014). The body size, age structure, and growth of Bosc's fringe-toed lizard, Acanthodactylus boskianus (Daudin, 1802). Turkish Journal of Zoology, 38, 383-388.

[14] Strijbosch, H., \& Creemers, R. C. M. (1988). Comparative demography of sympatric populations of Lacerta vivipara and L. agilis. Oecologia, 76, 20-26.

[15] Olsson, M., \& Shine, R. (1996). Does reproductive success increase with age or with size in species with indeterminate growth - a case study using sand lizards (Lacerta agilis). Oecologia, 105, 175-178.

[16] Guarino, F. M., Gia, I. D., \& Sindaco, R. (2010). Age and growth of the sand lizards (Lacerta agilis) from a high alpine population of north-western Italy. Acta Herpetologica, 5, 23-29.

[17] Kidov, A. A., Timoshina, A. L., Khairutdinov, I. Z., Kovrina, E. G., \& Matushkina, K. A. (2014). Age, growth and reproduction of the Bohme's lizard, Lacerta agilis boemica SUCHOV 1929 (Reptilia: Lacetilia: Lacertidae) in the foothills of North Ossetia. Vestnik of Buryat State University, 4(2), 49-52.

[18] Guarino, F. M., Crovetto, F., Mezzasalma, M., \& Salvidio, S. (2015). Population size, age structure and life expectancy in a Lacerta agilis population from northwest Italian Alps. North Western Journal of Zoology, 11, 241-246.

[19] Gül, S., Özdemir, N., Avc1, A., Kumlutaş, Y., \& Ilgaz, Ç. (2015). Altitudinal effects on the life history of the Anatolian lizard (Apathya cappadocica, Werner 1902) from southeastern Anatolia, Turkey. Turkish Journal of Zoology, 39, 507-512.

[20] Gül, S., Ilgaz, Ç. Kumlutaş, Y., \& Candan, K. (2017). Age structure and growth pattern in an east Anatolian high altitude population of Iranolacerta brandtii (De Filippi, 1863) (Squamata: Sauria: Lacertidae). Herpetozoa, 30 , 3-7.

[21] Altunışık, A., \& Eksilmez, H. (2018). Demographic life history traits in a population of a critically endangered species, Darevskia dryada (Darevsky \& Tuniyev, 1997). Animal Biology, 68, 27-37.

[22] Beşer, N., Ilgaz, Ç., Kumlutaş, Y., Avc1, A., Candan, K., \& Üzüm, N. (2019). Age structure and body size of a critically endangered species, Acanthodactylus harranensis (Squamata: Lacertidae) and its demography. Animal Biology, 69, 421-431.

[23] Tsms (2020). Turkish State Meteorological Service. < https://www.mgm.gov.tr> Ministry of Agriculture and Forestry, Ankara, Turkey. Accessed 11 May 2019.

[24] Lovich, J. E., \& Gibbons, J. W. (1992). A review of techniques for quantifying sexual size dimorphism. Growth Development and Aging, 56, 269-281.

[25] Gharzi, A., \& Yari, A. (2013). Age determination in the Snake-eyed Lizard, Ophisops elegans by means of skeletochronology (Reptilia: Lacertidae). Zoology in the Middle East, 59(1), 10-15.

[26] Bouragaoui, Z., \& Nouira, S. (2019). Age determination in the Sans Lizard Psammodromus algirus (Reptilia: Lacertidae) by means of skeletochronology. Current Herpetology, 38(2), 173-179.

[27] Bülbül, U., Kurnaz, M., \& Eroğlu, İ. (2016). Body size and age structure of the endangered Clark's lizard (Darevskia clarkorum) populations from two different altitudes in Turkey. Amphibia-Reptilia, 37, 450-456.

[28] Zhang, L., \& Lu, X. (2012). Amphibians live longer at higher altitudes but not at higher latitudes. Biological Journal of the Linnean Society, 106, 623-632.

[29] Cox, R. M., Butler, M. A., \& John-Alder, H. B. (2007). The evolution of sexual size dimorphism in reptiles. p. 38-49. In: D. J. Fairbairn, T. Szekely, and W. Blanckenhorn (eds.), Sex, size and gender Roles: evolutionary studies of sexual size dimorphism. Oxford University Press, Oxford, UK.

[30] Altunışık, A., Ergül-Kalaycı, T., Uysal, İ., Tosunoğlu, M., \& Özdemir, N. (2016). Age, adult survival rate and adult life expectancy of Podarcis tauricus population (Reptilia: Lacertidae) from Saros Bay. Turkey. Russian Journal of Herpetology, 23, 278-282.

[31] Manicom, C., Alford, R., Schoener, T. W., \& Schwarzkopf, L. (2014). Mechanisms causing variation in sexual size dimorphism in three sympatric, congeneric lizards. Ecology, 85, 1531-1544.

[32] Kurnaz, M., Bülbül, U., Eroğlu, A. İ., Uzun, F., Koç, H., \& Kutrup, B. (2018). Age and growth of the artvin Lizard, Darevskia derjugini (NIKOLSKY, 1898), in Turkey (Squamata: Sauria: Lacertidae). Herpetozoa, 30, 147-158.

[33] Roitberg, E. S. (2007). Variation in sexual size dimorphism within a widespread lizard species. p. 143-153. In: D. J. Fairbairn, T. Szekely, and W. U. Blanckenhorn (Eds.). Sex, size and gender Roles: evolutionary studies of sexual size dimorphism. Oxford University Press, Oxford, UK.

[34] Jimenez-Arcos, V. H., Sanabria-Urban, S., \& Cueva del Castillo, R. (2017). The interplay between natural and sexual selection in the evolution of sexual size dimorphism in Sceloporus lizards (Squamata: Phrynosomatidae). Ecology and Evolution, 7, 905-917.

[35] Roitberg, E. S., Eplanova, G. V., Kotenko, T. I., Carretero, M. A., Kuranova, V. N., Bulakhova, N. A., Zinenko, O. I., \& Yakovlev, V. A. (2015). Geographic variation of life-history traits in the sand lizard, Lacerta agilis: testing Darwin's fecundity-advantage hypothesis. Journal of Evolutionary Biology, 28, 613-629. 